\title{
Robotics Simulators in STEM Education
}

\author{
Agostinho Iaqchan Ryokiti Homa ${ }^{a}$ \\ a Universidade Luterana do Brasil (ULBRA), Programa de Pós-graduação em Ensino de Ciências e Matemática \\ (PPGECIM), Canoas, RS, Brasil.
}

Received for publication on 19 Sep. 2019. Accepted, after revision, on 24 Sep. 2019. Assigned editor: Claudia Lisete Oliveira Groenwald.

\begin{abstract}
This article discusses STEM (Science, Technology, Engineering and Mathematics) education as an initiative from various countries around the world to address young people's lack of interest in careers in Science, Mathematics, Technology and Engineering. Understanding that STEM education must explore two or more of STEM themes, using transdisciplinarity, engaging the student in activities with this approach, we present the studies of an activity proposal integrating Engineering, Technology and Mathematics with the objective of learning Mathematics. In this activity students work with situations involving robotics and, for solution, use robotic arm simulators, developed in GeoGebra software, that simplify the real environment in which the robotic arm manipulates an object positioned in the plane, taking to organize strategies by identifying and applying mathematics, such as trigonometry with right triangle, trigonometric identities, inverse trigonometric functions, to solve the problem. An experiment was conducted to validate the simulators with undergraduate mathematics students from Universidade Luterana do Brasil (ULBRA) in the city of Canoas in the Rio Grande do Sul state. The results indicate that it is possible to integrate the STEM areas with the developed simulators, being indicated for activities with high school students (10th or 11 th grade).
\end{abstract}

Keywords: STEM; Mathematics Education; Simulators.

\section{Simuladores Robóticos na Educação STEM}

\section{RESUMO}

Este artigo discute a educação STEM (Science, Technology, Engineering and Mathematics) como uma iniciativa de diversos países do mundo para tentar solucionar a falta de interesse dos jovens nas carreiras ligadas às áreas de exatas, especificamente, Ciência, Matemática, Tecnologia e Engenharia. Entendendo que a educação STEM deve explorar o ensino e a aprendizagem que envolva dois ou mais dos temas STEM, usando a transdisciplinaridade, engajando o aluno em atividades com este enfoque, apresenta-se uma proposta de atividade integrando a Engenharia, Tecnologia e a Matemática com o objetivo da aprendizagem da Matemática. Nesta atividade os estudantes resolvem situações envolvendo a robótica e, para solução, utilizam-se de simuladores de braços robóticos, desenvolvidos no software GeoGebra, que reproduzem de maneira simplificada o ambiente real no qual o braço robótico manipula um objeto posicionado no plano, levando-os

Corresponding author: Agostinho laqchan Ryokiti Homa. E-mail: iaqchan@hotmail.com.

\begin{tabular}{|l|l|l|l|l|l|}
\hline Acta Scientiae & Canoas & Vol. 21 & N. 5 & p.178-191 & Sep./Oct. 2019 \\
\hline
\end{tabular}


a organizar estratégias, identificando e aplicando conceitos de Matemática, para a solução do problema. Foi realizado um experimento de validação dos simuladores com alunos de licenciatura em Matemática, da Universidade Luterana do Brasil (ULBRA), do município de Canoas, no Rio Grande do Sul. Os resultados apontam que é possível a integração das áreas STEM com os simuladores desenvolvidos, sendo indicado para atividades com alunos do Ensino Médio ( $1^{\circ}$ ou $2^{\circ}$ anos).

Palavras-chave: STEM. Educação Matemática. Simuladores.

\section{INTRODUCTION}

There are currently worldwide concerns about the decline in high school students' interest in to pursue exact sciences careers. Departments of education in various countries identify this as a problem for the scientific development of countries, leading to the development of various initiatives aimed at increasing interest in careers in the fields of Science, Technology, Engineering and Mathematics (STEM).

First, the National Science Foundation (NSF) used SMET as shorthand for Science, Mathematics, Engineering, and Technology, but it was changed to STEM because SMET sounded too much like smut. The NSF has used the term STEM to refer to the four separate and distinct fields of Science, Technology, Engineering, and Mathematics, and differs from STEM education which comes as an action to reverse student's lack of interest in pursuing STEM careers (Sanders, 2009).

Initiated in the United States of America (USA), STEM education has spread to countries that have identified themselves with the scenario of student's lack of interest in pursuing STEM careers. In Brazil, there is no historical evidence of a decreased interest in science, technology, engineering and mathematics careers; nevertheless, while STEM education is not part of national education policy, this may be a way to increase interest in such careers.

There are no actions reportedly associated with STEM education in Brazil, but the Ministry of Science and Technology (MST) of Brazil, since 2002, promotes and encourages projects such as the Science and Technology Week (STW) that takes place annually, its sixteenth edition occurred in 2019, with the theme Bioeconomics: Diversity and Wealth for Sustainable Development. This project has a national scope, and in 2018 there were almost 95 thousand activities in 1,506 Brazilian municipalities of all states, involving more than 1,500 institutions. Coordinated by the Ministry of Science, Technology, Innovations and Communications, STW is the largest science popularization event in Brazil and has the collaboration of universities and research institutions, schools, technological education institutes, Science and Technology (S\&T) centers and museums, scientific entities, research support foundations, environmental parks, conservation units, botanical and zoological gardens, state and municipal S\&T education secretariats, public and private companies, as well as NGOs and other civil society entities (Brasil, 2019).

STEM education aims to bring contemporary themes from the exact sciences to the classroom, seeking to incorporate computing, robotics, programming, engineering, 
technology, design, virtual environments, applications, smartphones, games, with a creative and task-oriented approach challenging.

It is understood that STEM education must explore teaching and learning that involves two or more STEM areas, using transdisciplinarity, and engaging the student in activities with this focus. The STEM education is not only a methodology but a school transformation movement, curriculum and teaching methodologies, working with STEM areas requiring more than bringing together the four areas within a classroom (Sanders, 2009).

In addition to integrating between areas, STEM education is based on projectbased learning, proposing hands-on activities that cannot be considered as activities with constructivist approaches but an education that values the action of students, educating by research, discussion, reflection and working with problem situations of modern life. According to Berndt and Groenwald (2009), projects seek answers to questions that are related to a theme previously chosen by students, teachers or others who are part of the school environment.

Another feature of STEM education is that in addition to the activities performed involving the knowledge of more than one area, they are organized in such a way that students are stimulated to participatory actions that seek peer socialization, characteristic of professional practice considered as one of the 21st-century skills (Bybee, 2010). Thus, the school becomes the transforming agent of the student, with the preparation of the student for professional life developing the necessary skills for the performance of professional activities (Breiner, Johnson, Harkness, \& Koehler, 2012).

In 2006, fifteen years after the emergence of the STEM education approach, data presented by OECD studies (2006) and the European Science Education Now report (Rocard, Csermely, Jorde, Walberg-Henriksson, \& Hemmo, 2007) showed that the growing lack of interest in STEM careers still persisted. In 2005 the Europeans, Science and Technology report (Eurobarometer, 2005) identified that over $80 \%$ of Europeans felt that young people's interest in science would be essential for Europe's future prosperity, but with $50 \%$ of the population interviewed considering that Science classes in school are not attractive enough.

Based on this information, the European Parliament and the Council proposed, in 2006, the Council Recommendation on Key Competences for Lifelong Learning, which was then updated in 2018. Such as the USA, Europe maintains in its current proposal actions to motivate young people to pursue careers in science, but now broadening the relationships between themes, also linking with the sciences of education, the arts and other disciplines for skills development in the fields of Science, Technology, Engineering and Mathematics (Comissão Europeia, 2018).

In this sense, this article presents simulators of robotic arms developed to perform educational actions for learning the mathematical contents such as polar representation, trigonometry with a right triangle, trigonometric identities and inverse trigonometric 
functions. The learning objects ${ }^{1}$ presented simulate reality phenomena in a virtual environment developed in GeoGebra software, being indicated to be worked with high school students (10th or 11th grade).

\section{SIMULATORS IN EDUCATION}

The technological appeal of virtual environments and games is considered by STEM education as potential integrative tools for the development of activities for the formation of professional life skills. An important simulation feature is that the reproduction of an environment or model is based on some behavior of reality, or scientific or natural phenomenon (D’Angelo et al., 2014; Psotka, 2013).

Simulation in education can be considered an essential educational tool because it allows interaction and experimentation in various scenarios, allowing students to observe, realize and test their conjectures, putting into practice their theoretical knowledge (D’Angelo et al., 2014).

Even reproducing a model or environment, it is important to highlight the difference between emulators and simulators. An emulator fully represents the environment or model in which interactions occur, being well known in computing for the development of programs for different platforms or devices, such as mobile phones. In this way, the developer tests his programs on cell phone emulators that allow testing in an environment that is just like the real one without having the cell phones. While the emulator represents reality, the simulator reproduces the conditions of a particular activity, functioning as a system that mimics the actual circumstances and can adopt different degrees of reality, reproducing part of the phenomena that are not really occurring.

Although technologies are in virtually every area, robotics and technology are closely associated, mainly because of the culture of films and TV that feature automatons endowed with artificial intelligence that, except for feelings, are in many situations more efficient than humans.

The Maker Culture ${ }^{2}$ in STEM education sees robotics and simulators as an instrument for studies involving Mathematics and Engineering (Stohlmann, Moore, \& Roehrig, 2012; Wu \& Anderson, 2015). Programs such as LEGO Education, with over 37 years working with teachers and education professionals, have been mobilizing along with teachers to prepare students for the challenges of the future, developing skills such as creation, collaborative work and continuous learning (Lego, 2019). These and other robotics initiatives have a high cost of implementation and execution, and therefore are not accessible to Brazilian public schools.

\footnotetext{
${ }^{1}$ Learning objects are any entity, digital or otherwise, that can be used, reused or referenced during the learning process using technology (Institute of Electrical and Electronics Engineers, 2002).

${ }^{2}$ The Maker Culture is part of a movement in which individuals use technology to produce and share artifacts with a wider community. In education learning occurs through practical experiences, researching, raising hypotheses working collaboratively (Cohen, Jones, Smith, \& Calandra, 2017).
} 
In this case, the simulators are a possibility for the development of the teaching process, allowing students to contact the robotics area, with the advantage of working with robots with different degrees of reality, allowing the simplification of the activities to be performed, allowing to explore situations with mathematical concepts applied in Engineering.

One of the fundamental pieces of knowledge in robotic arms is the understanding of space movements, so it is necessary to represent the point in space and linear transformations to solve robotic movement problems. The representation of the point in the plane by rectangular coordinates is seen in elementary school and forms the basis for the graphical representation of functions (high school subject). In mathematics the polar representation is presented for the geometrical representation of complex numbers, but it is also particularly useful in the representation of phenomena which involve the distance and its angular position of a point, as is the case with maritime navigation radars and aerial, the calculations of the planetary orbits, and the positions of the robotic arms that manipulate objects in the plane.

The following are two examples of simulators that can be used with high school students.

\section{ROBOTICS SIMULATORS}

According to Moore and Smith (2014), there are two ways to integrate content and engineering. One way is to integrate context in which the engineering project that is used as a motivator for learning some Mathematics / Science content, and engineering is not the learning objective, whose focus is centered on the content required for engineering problem solving; the other way is the integration of Mathematics / Science content with engineering thinking, so that the learning objective also includes engineering learning.

Activities were carried out with the integration of content involving Technology and Mathematics, which present problems of manipulation of robotic arms, developed in GeoGebra software, as an alternative to providing contact with robotics through digital technologies, involving real situations whose resolution involves the mathematical contents.

The use of real robotic arms involves technological apparatuses and care of their mechanisms that may present defects due to misuse, besides some real models are not easily transportable in quantity, making it difficult to use in the classroom. Thus, digital simulators have the advantages, such as: do not break, do not need to be transported, do not require configuration or mechanical adjustments, allow the simplification of reality allowing to keep the focus on the object of study. 


\section{SIMULATOR 1}

The simulator 1 has a robotic arm with 2 degrees of freedom: transverse rotation that allows the rotation of the arm about the central axis; transverse radial axis with the approach and departure movement of the claw or handle relative to the base.

The developed models were simplified avoiding overloading the computer in the calculations necessary for arm movement and reducing the degree of complexity of the problem compared to the commands and calculations necessary for the movement of a real robotic arm.

While a robotic arm, similar to Figure 1, with three joints of revolution and one prismatic, has four degrees of freedom, represented by the red and green arrows, the developed simulator represents only two degrees of freedom indicated by the green arrows.

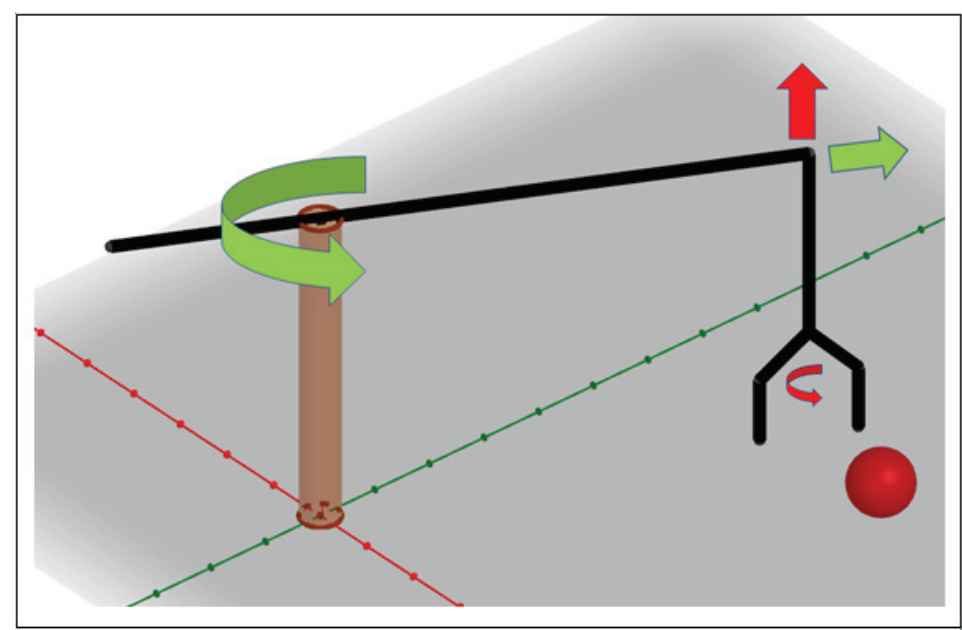

Figure 1. Robotic arm with three revolution joints and one prismatic.

The developed simulator is divided into three screens (Figure 2), the left screen is for controls, which tells the distance that the handle should move away from the base and the rotation angle, which can be given in positive or negatives values that translate into counterclockwise and clockwise movements respectively. The CAS (Computer Algebra System) screen from GeoGebra software is used for the necessary calculations and the three-dimensional window for viewing the robotic arm. The simulator has control to limit the random positioning of the ball only to the first quadrant when the Nova Bola (New Ball) button is pressed, reducing the degree of complexity of the problem situation. It is recommended that first situations to be solved by the students must be in the first quadrant and, after understanding them, it is possible for the ball to be positioned in any quadrant. 


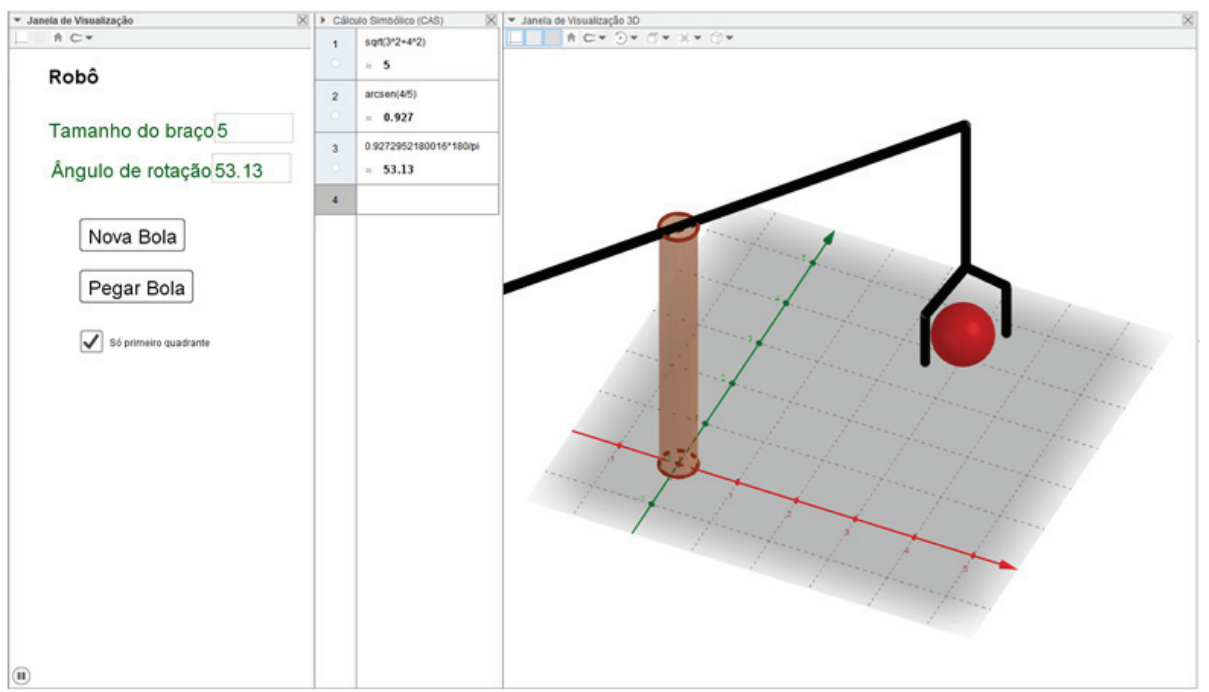

Figure 2. Robotic Arm Simulator 1.

After providing the extension and angle of rotation values of the robotic arm, the student must press the Pegar bola (Catch Ball) button so that the arm begins the ball catch movement and brings it close to the base at the coordinate $(1,0)$.

The activity presents an activity with the empirical understanding of the actions of the robotic arm, but in order to perform the action appropriately, it is necessary to use trigonometry with right triangles, trigonometric identities and inverse trigonometric functions to calculate the values to be provided to the simulator. The possibility of changing the point of view of the simulator in the three-dimensional window allows the student to identify the correct position of the ball on the XY plane.

\section{Proposal for Activity}

The activity can be started as a free activity with the goal of catching the ball, suggesting that the student arbitrarily place the angle measurement and how much the arm must extend to catch the ball successfully. After some attempts, the student verifies that the claw comes close but cannot catch the ball, so he is asked how to reach more accurate values for him to succeed in the action. At this time the teacher, according to the time available for the activity should, acting as a mediator, guides students in problemsolving, with questions such as:

- Considering the above view, which mathematical object is seen when the arm reaches the ball?

- Considering the coordinates of the ball, how big is the robot arm?

- How to calculate arm size? 
The questions aim for students to discuss and identify the right triangle and use trigonometric relationships (Pythagorean Theorem) to calculate how much the arm should extend as well as how much the arm should rotate when performing the calculation using trigonometric identities and respective inverse trigonometric functions:

$$
\begin{gathered}
\operatorname{sen}(\theta)=\frac{\text { opposite }}{\text { hypotenuse }} \\
\cos (\theta)=\frac{\text { adjacent }}{\text { hypotenuse }} \\
\tan (\theta)=\frac{\text { opposite }}{\text { adjacent }}
\end{gathered}
$$

The Geogebra software is poorly explored as (CAS) but, in the proposed activity, it can be used in place of the calculator. Figure 3 shows the commands in the CAS window for robotic arm extension and rotation calculations. The introduction to mathematical notation and computer mathematical commands is essential.

\begin{tabular}{|c|l|l|}
\hline \multicolumn{1}{|r|}{ Cálculo Simbólico (CAS) } & \multicolumn{1}{c|}{ CAS Commands } \\
\cline { 1 - 2 } 1 & $\begin{array}{l}\text { sqrt }\left(3^{\wedge} 2+4^{\wedge} 2\right) \\
\approx \mathbf{5}\end{array}$ & The command calculates $\sqrt{3^{2}+4^{2}}$ \\
\hline 2 & $\begin{array}{l}\text { arcsen(4/5) } \\
\mathbf{0 . 9 2 7}\end{array}$ & The angle of rotation is given by arcsen $\left(\frac{4}{5}\right)$ \\
\hline 3 & $\begin{array}{l}0.9272952180016^{\star} 180 / \mathrm{pi} \\
\mathbf{5 3 . 1 3}\end{array}$ & The calculation for converting radians to degrees \\
\hline
\end{tabular}

Figure 3. CAS commands for calculating the extension and rotation of the robotic arm.

To perform the calculations, the student can use the same CAS feature to calculate the hypotenuse value, as well as the rotation angle calculation. The student should be advised that the CAS works with radian measures and that, in this case, the simulator needs the rotation information in degrees, then the conversion of quantities should be performed before informing the simulator of the result of the angle.

With this simulator, the student has contact with the polar representation in a practical way and applied to a simulated reality context. Organizing the activity before presenting complex numbers in polar form, which requires a higher degree of abstraction, allows the student to visualize and properly apply trigonometric relations, visualizing an application for this mathematical content. 


\section{SIMULATOR 2}

The second simulator features a simplified robotic arm from five to three degrees of freedom, and the transverse movement of the first segment and claw is managed by the simulator itself. Thus, the student must enter the angle of rotation and the angle of the central articulation of the robotic arm that converts to the distance between the base of the robotic arm and the ball that the arm must catch.

Basically both simulators require the student to use polar representation, so that the robotic arm performs the action of catching the red ball, but the second simulator when representing an articulated arm brings with it the need to use and apply other mathematical tools for conversion of the distance between the base and the ball in the opening angle between the two segments of the robotic arm.

To calculate the arm joint angle, the student uses the Pythagorean theorem associated with the sum of the internal angles of the triangle, because the two segments are the same length, so an isosceles triangle is formed between the segments of the robotic arm. and the segment representing the distance from the base to the ball (Figure 4).

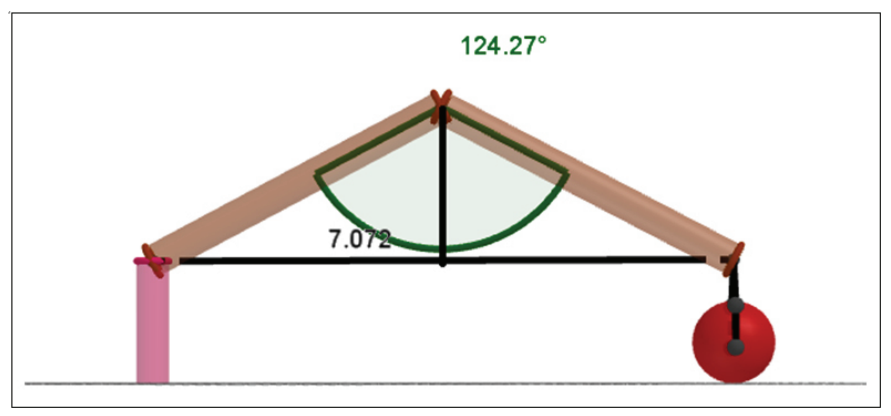

Figure 4. Position of the robotic arm when catching the ball.

If the student is familiar with the Cosine Law, it can be applied directly to the opening angle calculation that has the distance between the base and the ball as the opposite side to the angle. The Geogebra CAS software numerically calculates the equations that allow the calculation of the angle using $\mathrm{x}$ to denote the angle in the cosine law, and there is no need for the student to perform algebraic manipulations to isolate $\mathrm{x}$. The calculations shown in Figure 5 are presented. 


\begin{tabular}{|c|c|c|}
\hline \multicolumn{2}{|c|}{ - Cálculo Simbólico (CAS) } & CAS Commands \\
\hline 1 & $\operatorname{sqrt}\left(5^{\wedge} 2+5^{\wedge} 2\right)$ & The command calculates $\sqrt{5^{2}+5^{2}}$ \\
\hline O & $\approx 7.071$ & \\
\hline 2 & $\begin{array}{l}7.071^{\wedge} 2=4^{\wedge} 2+4^{\wedge} 2-2^{\star} 4^{\star} 4^{\star} \cos (x), x=1 \\
\text { ResolverNumericamente: }\{x=2.168\}\end{array}$ & $\begin{array}{l}\text { The calculation of the angle opposite } \\
\text { the segment of the triangle that } \\
\text { represents the distance from the base to } \\
\text { the ball. }\end{array}$ \\
\hline 3 & $\begin{array}{l}2.168^{*} 180 / \mathrm{pi} \\
\approx 124.217\end{array}$ & $\begin{array}{l}\text { The calculation for converting radians } \\
\text { to degrees }\end{array}$ \\
\hline 4 & $\operatorname{sen}^{-1}(5 / 7.071)$ & $\begin{array}{l}\text { The angle of rotation is given } \\
\text { by } \operatorname{arcsen}\left(\frac{3}{}\right)\end{array}$ \\
\hline O & $\approx 0.785$ & (5,830951894845 $)$ \\
\hline 5 & $\begin{array}{l}0.7854077535814^{\star} 180 / \mathrm{pi} \\
\approx 45.001\end{array}$ & $\begin{array}{l}\text { The calculation for converting radians } \\
\text { to degrees }\end{array}$ \\
\hline
\end{tabular}

Figure 5. CAS commands for calculating the opening and rotation angle of the robotic arm.

In Figure 6, there is a situation with the ball at the coordinate $(5,5)$ which in turn is at a distance of 7,071 from the base at the origin, which by the Law of cosines:

$$
7,071^{2}=4^{2}+4^{2}-2 * 4 * 4 * \cos (x)
$$

Using CAS to calculate the angle has the value of $x$ in 2,168 radians, being necessary the conversion be informed to the simulator the value of the angle in degrees. This need leads students to seek the knowledge necessary for the activity and, through reason:

$$
\begin{gathered}
\frac{\text { angle in degrees }}{180^{\circ}}=\frac{2.168}{\pi} \\
\text { angle in degrees }=\frac{2.168 * 180^{\circ}}{\pi}
\end{gathered}
$$

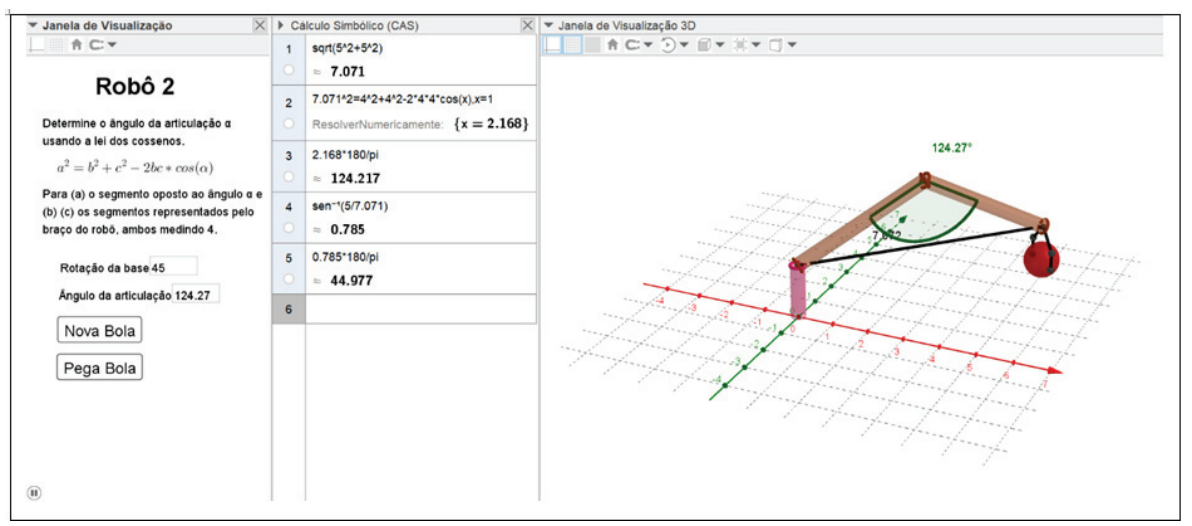

Figure 6. Robotic simulator 2 for learning the polar representation. 
The transverse movement of the base-linked segment and the jaw so that it remains perpendicular to the plane is managed by the simulator itself. By decreasing the degree of realism in a simulator, we seek to make it appropriate to the knowledge of the student who works with it.

\section{METHODOLOGY}

The general objective of this research was to identify the contributions of the use of simulators, using digital technologies, as a strategy in the teaching and learning process within the context of the integration of Mathematics contents in Engineering and Technology.

The investigation performed the following actions:

- Study of methodologies for the development of the teaching and learning process of Mathematics from the perspective of education in the assumptions STEM;

- Development of interactive robotic simulators for learning polar representations, using GeoGebra software;

- Development of an experiment to validate the simulators developed with undergraduate students of Mathematics at the Universidade Luterana do Brasil (ULBRA).

\section{RESULTS ANALYSIS}

The experiment took place in 3 hours, with five students enrolled in the Mathematics Internship II course of the ULBRA Mathematics Degree course. From the group of five students, three are in the 5 th semester, one in the 6 th semester and one in the 7 th semester of the course; two students teach in elementary school, and one teaches in high school classes.

For the accomplishment of the activity, five notebooks of the Mathematics laboratory were used, with the students working individually, but there were collective discussions about how to solve the activities with the simulators and with reflections on the activities.

According to them, it was possible to use a practical and exciting application of the right triangle and the cosine law; One of the students found it relevant to show a video of a backhoe or factory robot prior to the development of simulator activities so that they see that robots are not only in the movies but are used in real life.

During the activity one of the students could not solve the opening angle of the robotic arm, to catch the ball in position $(6,6)$ in the plane, i.e. the ball was 8,845 away 
from the base. This led to a group effort to solve the problem because they could not determine the value of $x$ for:

$$
8,845^{2}=4^{2}+4^{2}-2 * 4 * 4 * \cos (x)
$$

After some time of discussion and why the arm could not reach the ball, one of the students asked what the value of the $\arccos (1.25)$ was, and another student answered that there was no angle whose cosine would be greater than 1 . Analysing the problem situation, the students identified that for an arm composed of two size- 4 segments, it would be impossible to catch a ball that was 8,845 away from the base.

The generation of a random coordinate contemplates the coordinate restriction $(0,0)$ because the robot base is in this coordinate, not being considered the limitation of this situation in the coordinate generating routine. Despite this, the situation led to a fruitful discussion about the interpretation of the results of the calculations performed, and the validation of the value within the context in which it is inserted.

As they are students of the Mathematics Degree course, the discussions were also about how to do the activity with high school students, highlighting the importance that the students are protagonists and the teacher a mediator of the process; As well as the activity should be carried out collaboratively, in pairs or groups, to be able to discuss the resolution and presentation of the results obtained.

\section{FINAL CONSIDERATIONS}

The activity performed with the learning objects allowed to verify that in an open problem situation, the students first tried to solve by trial and error. After several attempts, they were informed that if the values were not accurate to the hundredths, the robot would not catch the ball. At this point, discussions began about how to solve the problem and what mathematical tools could be used to solve it, migrating from individual action to a collaborative one, with each one using the knowledge discussed to solve their individual problem, since each one had the ball at a different coordinate in their simulator.

Due to the nature of the group activity, the comments about the simulators ended up not being individual, but started by one and complemented by the others, which were pertinent to the continued development of the simulators. It was suggested that the leftover of the robotic arms be placed in the plane, as in a real situation, which would facilitate the identification of the right triangle; removing the connecting segment between the base and the claw by placing the distance information in the shadow of the arm; including the angle of rotation of the arm; and finally whether it would be possible to develop a robotic arm to pick up objects in space and not just in the plane.

The activity within the context of the integration of mathematical content in a problem situation of Engineering and Technology is considered adequate to the proposed primary objective of understanding polar representation as another way of representing the point in the plane. Having the mathematical contents necessary for the activity been 
worked in High School, it is considered that the proposed simulators are indicated for development for this school level.

\section{DATA AVAILABILITY STATEMENT}

Data sharing is not applicable to this article. The simulators developed are available on the website of the Graduate Program in Science and Mathematics Teaching, at http:// www.ppgecim.ulbra.br/math/geo/robo/.

\section{REFERENCES}

Berndt, S., \& Groenwald, C. L. O. (2009). Ensino da matemática na $5^{\mathrm{a}}$ serie do ensino fundamental: uma proposta com o tema transversal trabalho e consumo. In C. Maranhão (Ed.), Educação Matemática: nos anos finais do Ensino Fundamental e no Ensino Médio. Pesquisas e perspectivas (pp.212-233). Canoas: Musa Editora.

Brasil. (2019). Semana Nacional de Ciência e Tecnologia. Retrieved from https://snct. mctic.gov.br/semanact/opencms/noticias/index.html.

Breiner, J. M., Johnson, C. C., Harkness, S. S., \& Koehler, C. M. (2012). What Is STEM ? A Discussion About Conceptions of STEM in Education and Partnerships. School Science and Mathematics, 112(1), 3-11.

Bybee, B. R. W. (2010). Advancing STEM Education : A 2020 Vision. Technology and Engineering Teacher, (September 2010), 30-36.

Cohen, J., Jones, W. M., Smith, S., \& Calandra, B. (2017). Makification: Towards a framework for leveraging the maker movement in formal education. Journal of Educational Multimedia and Hypermedia, 26(3), 217-229.

Comissão Europeia. (2018). Recomendação do Conselho sobre as Competências Essenciais para a Aprendizagem ao Longo da Vida. Bruxelas.

D’Angelo, C., Rutstein, D., Harris, C., Bernard, R., Borokhovski, E., \& Haertel, G. (2014). Simulations for STEM Learning : Systematic Review and Meta-Analysis. Melo Park, CA: SRI Education.

Eurobarometer. (2005). Europeans, Science and Technology. Bruxelas.

Institute of Electrical and Electronics Engineers. (2002). IEEE Standard for Learning Object Metadata. Retrieved March 5, 2013, from http://grouper.ieee.org/groups/ltsc/ wg12/.

Lego. (2019). Lego Education. Retrieved July 23, 2019, from https://education.lego. com/en-us/about-us.

Moore, T. J., \& Smith, K. A. (2014). Advancing the State of the Art of STEM Integration. Journal of STEM E Duc a Tion, 15(1), 5-11.

OECD. (2006). Graduate Education in Physics: The Path Ahead-AConference to Discuss the Status and Future of Graduate Education in Physics. Policy Report, 31(3), 127-149. https://doi.org/10.1056/nejm193907202210308. 
Psotka, J. (2013). Educational Games and Virtual Reality as Disruptive Technologies. Educational Technology \& Society, 16(2), 69-80.

Rocard, M., Csermely, P., Jorde, D., Walberg-Henriksson, H., \& Hemmo, V. (2007). A Renewed Pedagogy for the Future of Europe. Economy and Society, 29. Retrieved from http://ec.europa.eu/research/science-society/document_library/pdf 06/report-rocard-onscience-education_en.pdf.

Sanders, M. (2009). STEM, STEM Education, STEMmania, 20-27.

Stohlmann, M., Moore, T. J., \& Roehrig, G. H. (2012). Considerations for Teaching Integrated STEM Education. Journal of Pre-College Engineering Education Research, 2(1). https://doi.org/10.5703/1288284314653.

Wu, Y., \& Anderson, O. R. (2015). Technology-enhanced STEM (science, technology, engineering, and mathematics) education. Journal of Computers in Education, 2(3), 245-249. https://doi.org/10.1007/s40692-015-0041-2. 